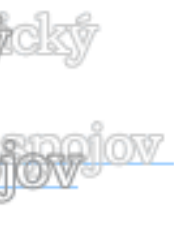

\title{
CROWDFUNDINGOVÉ PLATFORMY A ICH KOMPARÁCIA NA ZÁKLADE PÔSOBNOSTI
}

\author{
Mária Žilinčíková ${ }^{1}$
}

\begin{abstract}
At present, companies operate various forms of financing to finance their projects. One of these resources that comes to the fore is crowdfunding platforms. Therefore, the aim of the article is to compare crowdfunding platforms in selected countries. The comparison focuses on the crowdfung platforms Starter and Hithit in terms of remuneration criteria.
\end{abstract}

Keywords: contributor, crowdfunding, e-commerce, optimization.

\section{Úvod}

Podniky hl'adajú rôzne cesty na financovanie svojich podnikov. Zdroje financovania zahŕňajú priatel'ov, zamestnancov, externých investorov alebo klientov. Okrem subjektov môžu byt' zdrojmi financovania dary, granty, predchádzajúci zisk a d'alšie spôsoby financovania ich projektov $[1,2]$. V súčasnej dobe podniky využívajú popri týchto rozmanitých zdrojoch financovania aj crowdfundingové platformy.

Pojem crowdfunding je charakterizovaný ako metóda získavania financií pri vzniku projektov pomocou mikropríspevkov od rôznorodého množstva prispievatel'ov (jednotlivec, skupina, dar, podnik a od mnohých iných právnych foriem) [3]. Rovnako reprezentuje hromadné financovanie.

V časovom horizonte do roku 2030, sa predpokladá, že v dôsledku digitalizácie spoločnosti bude pomer novovzniknutých pracovných miest $\mathrm{k}$ zaniknutým $2: 5$. Rovnako to platí aj pri financovaní projektov, ktoré prinášajú nové smery ako „,business angels“ (Klub podnikatel'ských anjelov v Slovenskej republike), crowdfunding, fundraising. Dnešná doba je charakteristická tzv. ,,sharing economy“ (zdiel'anou ekonomikou) a všetko sa prispôsobuje webovým platformám, ktoré vytvárajú miesto, kde sa stretávajú bežní spotrebitel’a a podnikatelia [4].

Prostredníctvom crowdfundingu malé podniky oslovujú jednotlivcov a iné subjekty, aby im svojimi príspevkami umožnili financovanie ich projektov, ktoré majú v pláne uskutočnit'. Zbierka funguje pomocou malých príspevkov od jednotlivých subjektov (občan, fyzická osoba, právnická osoba a pod.). Uvedený subjekt sa spravidla skladá malou čiastkou na kampaň, ktorá vedie ku kombinovanému financovaniu. Predmetné investovanie jednotlivca je adekvátne pre malých investorov. Na druhej strane napomáha tvorcom projektov k splneniu vytvoreného projektu, ktorý by inak nemohli realizovat'. Aktuálnym trendom je dížka projektu, respektíve kampane, ktorá sa nachádza v rozmedzí od 30 dní a viac [5].

Crowdfunding vznikol $\mathrm{z}$ crowdsourcingu, ktorý sa vyznačuje používaním davu na nadobudnutie a uskutočnenie nápadov, inšpirácie, taktiež spätnej väzby, rovnako zložitých riešení [6]. Samotný crowdfunding funguje niekol'kými spôsobmi ako:

\footnotetext{
${ }^{1}$ Ing. Mária Žilinčíková, Katedra spojov, FPEDAS, Žilinská univerzita v Žiline, e-mail: maria.zilincikova@fpedas.uniza.sk
} 
- Charitatívna verzia - v tejto forme darca neobdrží nič ako protihodnotu za svoj príspevok do projektu. Uvedeným spôsobom sa uhrádzajú predovšetkým projekty charít či iných neziskových organizácií.

- Predpredajová verzia - v uvedenom druhu poberá darca za svoj príspevok nejakú odmenu z úspešného projektu. Spravidla je priamo zodpovedajúca výške jeho daru. Práve túto verziu preferujú napríklad rôznorodí umelci či začínajúci podnikatelia a pod.

- Podielová verzia - je zameraná na taký spôsob financovania, v ktorom darca za jeho príspevok nadobudne primeranú čast' podniku. Preto je tento druh zhodný s klasickým investovaním do podnikov alebo jeho častí. Diferencia je $\mathrm{v}$ tom, že účast' $\mathrm{v}$ podniku je väčšinou až po úspešnom uskutočnení projektu. Zisk sa v tomto prípade pohybuje rádovo v desiatkach eur alebo dolárov. Podielový davový príspevok zužitkovávajú hlavne startupy, ktoré takouto formou dokážu vyzbierat' peniaze na svoj rozbeh v podnikaní.

- Pôžičková verzia - reprezentuje druh mikroúverov. Odlišnost' spočíva v tom, že peňažné prostriedky nepožičiava banka, ale niekol'ko drobnejších súkromných sponzorov. Pôžičkovú podobu crowdfundingu si vyberajú najmä podniky, ktoré by iným spôsobom nemali šancu na požičanie peňazí v banke [7].

\section{Formy crowdfundingu}

Crowdfunding sa implementoval ako alternatívna možnost' financovania sociálnych podnikov v krajinách, kde nastali počiatočné alebo rozširovacie fázy rozvoja. Práve crowdfunding umožňuje proces financovania prostredníctvom platformy, ktorá napomáha jednotlivcom realizovat' nápady alebo projekty pomocou nízkeho objemu kapitálu. Rovnako crowdfunding je výhodnou alternatívou, cez ktorú môžu l'udia zdiel'at' svoje nápady s ostatnými [8]. Tento smer je v súčasnosti považovaný za novodobý prostriedok financovania malých aj vel'kých projektov. Čoraz viac sa tejto problematike začínajú venovat' aj na akademickej pôde. Problematikou crowdfundingu sa už od roku 2014 zaoberajú Neubaum, Meyskens, Mollick. Takisto o predmetnej problematike pojednávajú práce autorov ako Belleflamme, Centobelli, Gore, Hoffman, Hui, Indiegogo, Kiva, Lambert, Lehner, Lyons, Mair, Martínez-Climent, Meyskens, Özdemir a Schweinbacher.

Tabul'ka 1. Aktívne slovenské crowdfundingové webové platformy

\begin{tabular}{|c|c|c|c|}
\hline \multicolumn{2}{|c|}{ Forma crowdfundingu } & Názov platformy & Webová stránka platformy \\
\hline \multirow{4}{*}{\multicolumn{2}{|c|}{ Na báze darov }} & Ďakujeme sme & http://dakujeme.sme.sk \\
\hline & & Dobrá krajina & http://www.dobrakrajina.sk \\
\hline & & L'udia l'ud'om & https://www.ludialudom.sk \\
\hline & & Srdce pre deti & https://www.srdcepredeti.sk \\
\hline \multirow{2}{*}{\multicolumn{2}{|c|}{ Na báze odmeny }} & Hithit & https://www.hithit.com/ \\
\hline & & StarLab & https://www.startlab.sk \\
\hline \multirow{6}{*}{$\begin{array}{l}\text { Na báze } \\
\text { odmeny }\end{array}$} & \multirow{2}{*}{ Bussiness lending } & Conda & https://www.conda.sk \\
\hline & & Finnest & https://www.finnest.com/sk \\
\hline & \multirow{4}{*}{ P2P lending } & Investuješ & https://www.investujes.sk \\
\hline & & Maják & https://majak.sk/\#/ \\
\hline & & Zinc Euro & https://www.zinceuro.sk \\
\hline & & Žltý melón & https://www.zltymelon.sk \\
\hline \multicolumn{2}{|c|}{ Na báze majetkovej účasti } & Crowdberry & https://www.crowdberry.sk \\
\hline
\end{tabular}

Zdroj: vlastné spracovanie podl'a $[7,9,10]$

Uvedené webové platformy sa odlišujú $\mathrm{v}$ závislosti od typu crowdfundingu, ktorý reprezentujú. Každá z nich dodržuje záväzné právne predpisy, neriadia sa nekalými 
obchodnými praktikami. Rovnako nepreferujú neprijatel'né zmluvné podmienky a dbajú na prevádzkovanie vlastnej platformy pri dodržiavaní týchto zásad etických pravidiel:

- Princípy etických pravidiel dodržiavajú prevádzkovatelia crowdfundingových platforiem prijatých na území Slovenskej republiky.

- Prevádzkovatel' crowdfundingovej platformy prevádzkuje svoju platformu v súlade $\mathrm{s}$ etickými predpismi správania sa $\mathrm{v}$ zákonitosti transparentnosti, nediskriminácie, dôvery a otvorenosti informácií. Za týmto účelom boli vytvorené pravidlá ohl'adom informácií a ich zverejňovania.

Prevádzkovatel' crowdfundingovej webovej platformy dbá na prehl'adné a kompletné zverejnenie informácií o fungovaní platformy, totožne pre podporované projekty, takisto pre investorov (darcov). Taktiež dáva pozor na prehl'adné a úplné zverejnenie informácií o poplatkoch alebo o princípe odmeňovania a potenciálnych konfliktoch záujmov prevádzkovatel'a platformy [10].

Stará sa o informačné a priebežné zverejňovanie dát o projektoch, v prípade, že platforma umožňuje $\mathrm{k}$ financovanie projektov. Takisto dáva pozor na nezverejňovanie neodôvodnených informácií o prednostiach projektov, predovšetkým o výnosoch. Odkrýva nekalé obchodné praktiky a taktiež klamlivú reklamu. Aktualizuje v pravidelných intervaloch prehl'adné zverejňovanie rizík spájajúcich sa s investovaním alebo darovaním peňažných prostriedkov pomocou tejto webovej platformy. Dozerá na zachovanie nediskriminačného pomeru projektov aj investorov (darcov) $\mathrm{k}$ službám platforiem. Dohliada na integritu pri poskytovaní služieb platformy. Dbá na kontrolu plnenia svojich povinností pri ochrane osobných údajov a súkromia investorov (darcov) podla pravidiel legislatívy ku GDPR.

Pokial' samotný prevádzkovatel' webovej crowdfundingovej platformy vedie financie investorov (darcov), tak ich má $\mathrm{v}$ oddelenej evidencii od svojich finančných prostriedkov [10].

\section{Ciel' a metodológia}

Ciel’om článku je komparácia crowdfundingových webových platforiem pôsobiacich v Slovenskej a Českej republike. V tomto článku boli využité metódy ako sú metóda excerpovania, metóda abstrakcie, metóda komparácie, metóda indukcie a dedukcie a metóda syntézy. Metóda excerpovania bola aplikovaná pri štúdiu odbornej literatúry od rôznorodých autorov. Metóda abstrakcie bola využitá na zúženie skúmanej teoretickej problematiky z vel'kého množstva názorov individuálnych autorov na predmetnú problematiku. Výskum sa zameriava na analýzu a následnú komparáciu dvoch vybraných crowdfundingových webových platforiem. Uvedené platformy boli vyselektované na základe najväčšej podobnosti porovnávacích kritérií. Porovnávacie kritériá boli zvolené so zretel'om na všeobecné subjektívne požiadavky prispievatel'ov na uvedené crowdfundingové webové platformy.

\section{Výsledky}

Prevádzkovatelia crowdfundingových webových platforiem, ktoré fungujú v Slovenskej republike za účelom zakladania a vplyvu v transparentnom prostredí, prikročili k spoločnej iniciatíve dodržiavania zákonitostí a etických pravidiel crowdfundingových webových platforiem na území Slovenskej republiky [11].

Tabul'ka 2. Komparácia crowdfundingových webových platforiem Hithit a Startovač

\begin{tabular}{|l|c|c|}
\hline & Startovač & Hithit \\
\hline
\end{tabular}




\begin{tabular}{|c|c|c|c|}
\hline \multicolumn{2}{|c|}{ Vznik } & 2013 & 2012 \\
\hline \multicolumn{2}{|c|}{ Územie } & Česká republika & Slovenská republika \\
\hline \multicolumn{2}{|c|}{ Typ crowdfundingu } & Odmenový & Odmenový \\
\hline \multicolumn{2}{|c|}{ Mena } & EUR/CZK & EUR/CZK \\
\hline \multicolumn{2}{|l|}{ Web } & www.startovac.cz & www.hithit.com \\
\hline \multicolumn{2}{|c|}{ Typ financovania } & Fixné & Fixné \\
\hline \multicolumn{2}{|c|}{ Platobná brána } & PayPal & GomGate \\
\hline \multicolumn{2}{|c|}{ Druh projektu } & $\begin{array}{l}\text { L’ubovol'ný (musí byt' schválený prevádzkovatel'om webovej } \\
\text { platformy) }\end{array}$ & $\begin{array}{c}\text { Lubovol'ný (musí byt' schválený } \\
\text { prevádzkovatel'om webovej } \\
\text { platformy) }\end{array}$ \\
\hline \multicolumn{2}{|c|}{ Doba trvania zbierky } & 15,30 alebo 60 dní & Maximálne 45 dní \\
\hline \multicolumn{2}{|c|}{ Minimálny príspevok } & Kč 50,-- & Kč $10,--$ \\
\hline \multicolumn{2}{|c|}{ Minimálna provízia } & Odporúčaná čiastka prevádzkovatel'om je Kč 100,-- & Kč $10,--$ \\
\hline $\begin{array}{l}\text { Výška odmeny } \\
\text { pre } \\
\text { prevádzkovatel'a } \\
\text { úspešný projekt }\end{array}$ & $\begin{array}{l}\text { Projekty v } \\
\text { EUR }\end{array}$ & $\begin{array}{c}5 \% \text { (vrátane DPH) pri ciel'ovej čiastke projektu }>=\text { Kč } 500000,-- \\
7 \% \text { (vrátane DPH) pri ciel'ovej čiastke projektu }>=\text { Kč } 50000,-- \\
9 \% \text { (vrátane DPH) pri ciel'ovej čiastke projektu }<\text { Kč } 50000,-- \\
5 \% \text { (vrátane DPH) pri ciel'ovej čiastke projektu }>=€ 20000,-- \\
7 \%(\text { vrátane DPH) pri ciel'ovej čiastke projektu }>=€ 2000,-- \\
9 \% \text { (vrátane DPH) pri ciel'ovej čiastke projektu }<€ 2000,--\end{array}$ & $\begin{array}{c}\text { Čiastka do Kč } 200000,-- \\
\text { alebo do } € 7500,--9 \% \text { (+ DPH } \\
\text { podl'a zákonnej výšky) } \\
\text { z celkovej vyzbieranej sumy } \\
\text { Projektu + Kč } 699,-- \\
\text { administratívny poplatok } \\
\text { nad Kč } 200000,-- \\
\text { alebo do } € 7500,-- \text { odmena } \\
\text { individuálna }\end{array}$ \\
\hline \multicolumn{2}{|c|}{$\begin{array}{c}\text { Výška odmeny pre } \\
\text { prevádzkovatel'a neúspešný } \\
\text { projekt }\end{array}$} & Žiadna provízia & Žiadna provízia \\
\hline \multirow{2}{*}{$\begin{array}{l}\text { Transakčné } \\
\text { poplatky } \\
\text { úspešného } \\
\text { projektu }\end{array}$} & $\begin{array}{l}\text { Project in } \\
\text { CZK }\end{array}$ & 1,25 až $3,5 \%$ & $1,5 \%+\mathrm{Kč} 1,--$ \\
\hline & $\begin{array}{l}\text { Project in } \\
\text { EUR }\end{array}$ & $1,25 \mathrm{až} 3,5 \%$ & $1,5 \%+€ 0,10$ \\
\hline \multicolumn{2}{|c|}{$\begin{array}{l}\text { Transakčné poplatky } \\
\text { neúspešný projekt }\end{array}$} & Kč 0,--/€ 0,-- & Kč 0,--/€ 0,-- \\
\hline \multirow{2}{*}{$\begin{array}{l}\text { Kto hradí } \\
\text { poplatky }\end{array}$} & $\begin{array}{l}\text { Úspešný } \\
\text { projekt }\end{array}$ & Zakladatel' projektu & Zakladatel' projektu \\
\hline & $\begin{array}{l}\text { Neúspešný } \\
\text { projekt }\end{array}$ & Prispievatel' & Prispievatel' \\
\hline \multicolumn{2}{|c|}{ Skončenie projektu } & Uplynutím doby trvania projektu & Uplynutím doby trvania projektu \\
\hline \multicolumn{2}{|c|}{ Užívatel'ská podpora } & $24 / 7$ & $24 / 7$ \\
\hline
\end{tabular}

Zdroj: vlastné spracovanie podl'a [7, 9, 10]

V Tabul'ke č. 2 vyššie sú uvedené dva typy crowdfundingových webových platforiem. Sú vybrané z hl'adiska najväčšej podobnosti a porovnatel'nosti. Obe crowdfundingové webové platformy nemajú dlhú históriu fungovania. Vznikli v podobnom období v roku 2012 a 2013. Dobré meno si vybudovali aj napriek tomu, že zatial' nefungujú ani jednu dekádu. Startovač aj Hithit predstavujú odmenové webové platformy, ktoré uverejňujú akýkol'vek projekt či zbierku. Sú odsúhlasené prevádzkovatel’om s výnimkou charitatívnych projektov.

Pri konkrétnom projekte zohráva dôležitú úlohu druh financovania. Crowdfundingové webové platformy Hithit a Startovač dávajú možnost' svojim prispievatel'om a klientom fungovat' len prostredníctvom fixného financovania. Zameriavajú sa na projekty na území Slovenskej a Českej republiky. Výhoda, ktorá ich posúva vpred je, že dávajú možnost' svojim 
prispievatel'om pri výbere meny medzi CZK a EUR. Platobná brána je rôzna, Startovač používa PayPal a Hithit využíva GomGate. Doba trvania zbierky znamená, aký časový priestor má žiadatel' na naplnenie ciel'ovej čiastky projektu. Najdlhšie časové obdobie umožňuje Startovač, a to až 60 dní. Rovnako dáva možnost' výberu medzi 15, 30 a 60 dňami trvania zbierky. Naproti tomu crowdfundingová webová platforma Hithit limituje maximálny čas priebehu zbierky na 45 dňové obdobie.

Minimálna čiastka prispievatel'a na projekt sa líši. U Startovača je to Kč 50,--, u Hithit je to ovel'a menej, a to od Kč 10,--. Minimálna provízia, ktorú prispievatel' dostáva po ukončení úspešného projektu je rôznorodá. Najmenšia odmena sa pohybuje od Kč 10,--, ktorú dáva Hithit a najvyššia je odporúčaná prevádzkovatel'om platformy Startovač v čiastke Kč 100,---

V d’alšom kroku je náležité spomenút', že výška provízie, ktorú si daná crowdfundingová webová platforma odpočíta od ciel'ovej sumy projektu sa odlišuje podl'a projektu, ale aj podl'a crowdfungovej webovej platformy. Startovač sa riadi hranicami Kč $500000,--(€ 20000,--)$ a Kč $50000,--(€ 2000,--)$, od najnižšej provízie $5 \%, 7 \%$, po najvyššiu 9\%. Hithit predkladá odpočítanie 9\% pri vyzbieranej sume do Kč 200000 ,-(€ $7500,--)$. Následne pri väčších čiastkach sa percento znižuje. Takisto Hithit nemá vôbec uvedené pri sumách väčších ako Kč $200000,--$ (€ $7500,--)$ úroveň provízie. Práve z toho dôvodu, že každá provízia je individuálna podl’a druhu a trvania projektu. Pri neúspešných projektoch sa obe platformy zhodujú a nevyplácajú žiadne odmeny.

Rozdiely sú viditel'né aj pri transakčných poplatkoch. Pri úspešných projektoch uhrádza všetky transakčné poplatky zakladatel' projektu. Naopak pri neúspešných projektoch sa účtujú transakčné poplatky na stranu prispievatel'a. Výška najväčšieho transakčného poplatku na Hithit je stanovená vo výške $1,5 \%$ plus Kč 1,-- (€ 0,10,--). Z pohl'adu Startovača sa využívajú transakčné poplatky v rozpätí medzi $1,25 \%$ do $3,5 \%$. Vel'kou nevýhodou uvedenej crowdfundingovej webovej platformy sú vel'mi vysoké transakčné poplatky za príspevky zasielané pomocou SMS.

Tabul'ka 3. Stanovenie váh jednotlivým kritériám

\begin{tabular}{|l|c|}
\hline \multicolumn{1}{|c|}{ Kritérium } & Váha \\
\hline Výber typu CF & 8 \\
\hline Prehl'adné spracovanie webu & 7 \\
\hline Výška odmeny & 10 \\
\hline Druh projektu & 9 \\
\hline Doba trvania projektu & 5 \\
\hline Minimálny príspevok & 6 \\
\hline Možnost' výberu financovania & 7 \\
\hline Počet platobných metód & 6 \\
\hline Druh platobnej brány & 5 \\
\hline Platba poplatkov pri neúspešnom projekte & 9 \\
\hline Zdroj: vlastné spracovanie podla & \\
\hline
\end{tabular}

Zdroj: vlastné spracovanie podl'a [7, 9, 10]

V Tabul'ke č. 3 je viditel'ných 10 kritérií hodnotenia používatel'mi platformy. Najváženejšími kritériami sú výber typu crowdfundingovej platformy, výška odmeny prispievatel'a, druh projektu, platba poplatkov pri neúspešnom projekte. Jedným z najdôležitejších kritérií je výška provízie, ktorú musí zakladatel' projektu zaplatit' crowdfundingovej webovej platforme v prípade úspešného projektu. Najmenej dôležitejším kritériom je doba trvania kampane.

Tabul'ka 4. Vyhodnotenie jednotlivých variantov 


\begin{tabular}{|c|c|c|c|}
\hline Kritérium & Váha & Startovač & Hithit \\
\hline Výber typu CF & 8 & 7 & 7 \\
\hline Prehl'adné spracovanie webu & 7 & 4 & 7 \\
\hline Výška odmeny & 10 & 9 & 8 \\
\hline Druh projektu & 9 & 9 & 9 \\
\hline Doba trvania projektu & 5 & 4 & 3 \\
\hline Minimálny príspevok & 6 & 3 & 5 \\
\hline Možnost' výberu financovania & 7 & 5 & 5 \\
\hline Počet platobných metód & 6 & 4 & 4 \\
\hline Druh platobnej brány & 5 & 5 & 4 \\
\hline Platba poplatkov pri neúspešnom projekte & 9 & 8 & 8 \\
\hline Vážený súčet & & 449 & 462 \\
\hline Poradie & & 2 & 1 \\
\hline
\end{tabular}

Zdroj: vlastné spracovanie podla [7, 9, 10]

Následným uskutočnením komparácie a rozboru konkrétnych crowdfundingových webových platforiem Startovač a Hithit, ich kritérií s pridelenými váhami, je možné pridelit' jednotlivé bodové hodnotenia. $Z$ celkového výsledku je možné usúdit', že naozaj sú tieto dve crowdfundingové webové platformy porovnatel'né. Bodové hodnotenie sa líši len o 13 bodov. S lepším skóre skončila crowdfundingový webová platforma Hithit. Vedie predovšetkým v kritériách ako sú prehl'adné spracovanie webu, minimálny príspevok prispievatel'a. V ostatných kategóriách sú crowdfundingové webové platformy skoro identické. Startovač má menšiu výhodu vo výške odmeny pre prispievatel'a, dobe trvania projektu, druhu platobnej brány. Skončenie projektu pre jednotlivé projekty je možné uplynutím doby trvania projektu, tzn. v momente ukončenia projektu.

\section{Záver}

Na základe zistených výsledkov analýzy a následnej komparácie crowdfundingových webových platforiem Startovač a Hithit je možné konštatovat', že v Slovenskej a Českej republike sa začali používat' davové spôsoby financovania projektov, ktoré umožňujú zozbierat' finančné prostriedky aj takým spoločnostiam alebo začínajúcim podnikatel'om, ktorí by v bežnom tržnom prostredí nemali možnost' získat' finančné prostriedky od bežných investorov alebo banky. Vo vyššie uvedenej klasifikácii, v prostredí Slovenskej a Českej republiky, lepšie uspela crowdfundingová webová platforma Hithit svojou prehl'adnost'ou webovej stránky a minimálnym príspevkom pre prispievatel'a. V konečnom dôsledku je možné zosumarizovat', že pre prispievatel'a sú významné všetky kritéria, ktoré sa dotýkajú poskytovania finančných prostriedkov. Pre zakladatel'a projektu sú to doba trvania zbierky, výška odmeny prispievatel'ovi a transakčné poplatky pri úspešnom projekte. Pri prevádzkovatel'ovi sú jeho hlavnými kritériami pozornosti predovšetkým prehl'adné a kompletné zverejnenie informácií o fungovaní platformy, projekte, vhodne nastavené financovanie jednotlivých projektov, druh projektu a odhalovanie, prípadne zabránenie nekalým praktikám. Crowdfundingový spôsob financovania projektov je ešte len na začiatku, avšak jeho pôsobenie a rast nie je možné popriet'. [12, 13].

\section{Literatúra}

[1] LYONS, T.: Social Entrepreneurship: How Businesses Can Transform Society, 2010. Approaches to Financing Social Entrepreneurship, 2. Santa Barbara, CA: Praeger

[2] MEYSKENS, M., CARSRUD, A.: Nascent Green-Technology Ventures: An Exploratory Study Assessing the Role of Partnership Diversity in Firm Success, 2013. Small Business Economics 40 (3): 739-59 
[3] CENTOBElli, P., CERCHIONE, R., ESPOSITO, E., RAFFA, M.: The revolution of crowdfunding in social knowledge economy, 2016. Literature review and identification of business models. Advanced Science Letters, 22(5-6), 1666-1669

[4] Dopady digitalizace na trh práce v ČR a EU: Oddělení strategických trendů EU, OSTEU Discussion paper 12/2015

[5] GORE, E. M., DIGIAMMARINO, B.: Crowdfunding for Nonprofits (SSIR) [Web log post], 2014. Accessed November 11, 2014, [online]. [cit. 2020-10-02]. Dostupné na: http://www.ssireview.org/blog/entry/crowdfunding_for_nonprofits

[6] BELLEFLAMME, P., LAMBERT, T., SCHWIENBACHER, A.: Crowdfunding: An Industrial Organization Perspective, 2010. In Prepared for the Workshop Digital Business Models: Understanding Strategies', held in Paris on June (pp. 25-26)

[7] Získat' peniaze cez crowdfunding nie je l'ahké. Za pokus to však stojí. Www.eprogress.sk [online]. Bratislava: eProgress.sk, 2019, 25.9.2019. [cit. 2020-08-25]. Dostupné na: https://www.eprogress.sk/crowdfunding-definicia-a-platformy

[8] LEHNER, O. M.: Crowdfunding Social Ventures: A Model and Research Agenda, 2013. Venture Capital 15 (4): 289-311

[9] CF platformy. Crowdfunding.ciforum.sk [online]. Bratislava: Creative Industry Forum, 2018. [cit. 2020-06-02]. Dostupné na: https://crowdfunding.ciforum.sk/platforms

[10]MARTÍNEZ-CLIMENT, C., ZORIO-GRIMA, A., RIBEIRO-SORIANO, D.: Financial return crowdfunding: literature review and bibliometric analysis, 2018. International Entrepreneurship and Management Journal, 14(3), 527-553

[11]MEYSKENS, M., BIRD, L.: Crowdfunding and value creation. Entrepreneurship, 2015. Research Journal, 5(2), 155-166

[12]HUI, J. S., GERBER, E. M.: Crowdfunding science: Sharing research with an extended audience, 2015. In Proceedings of the 18th ACM Conference on Computer Supported Cooperative Work \& Social Computing (pp. 31-43)

[13] ÖZDEMIR, V., FARIS, J., SRIVASTAVA, S.: Crowdfunding 2.0: the next-generation philanthropy, 2015. EMBO reports, 16(3), 267-271 